\title{
Belphégor
}

\section{The Myth of May 1968 in bandes dessinées.}

\section{Matthew Screech}

\section{OpenEdition}

\section{Journals}

Electronic version

URL: http://journals.openedition.org/belphegor/1012

DOI: 10.4000/belphegor.1012

ISSN: 1499-7185

\section{Publisher}

LPCM

\section{Electronic reference}

Matthew Screech, "The Myth of May 1968 in bandes dessinées. », Belphégor [Online], 15-2 | 2017,

Online since 13 December 2017, connection on 01 May 2019. URL : http://journals.openedition.org/ belphegor/1012; DOI : 10.4000/belphegor.1012

This text was automatically generated on 1 May 2019.

\section{(c) (1) $8 \odot$}

Belphégor est mis à disposition selon les termes de la Licence Creative Commons Attribution - Pas d'Utilisation Commerciale - Pas de Modification 4.0 International. 


\title{
The Myth of May 1968 in bandes dessinées.
}

\author{
Matthew Screech
}

\section{Introduction}

1 The events of May 1968, when potentially revolutionary unrest nearly brought down the French government, have entered the national mythology: over time, the popular imagination has simplified this complex historical moment into an exemplary story of hedonistic, student-led socio-cultural liberation; that easily comprehensible narrative is widely believed without question, and it informs the public's perception of what happened. The Larousse Dictionnaire de Mai 68 gives a useful and concise definition of the "Mai mythique": "Simplifié, réduit à quelques grands moments ludiques et à quelques images largement diffusées, Mai 68 est devenu progressivement une date référence, point de départ d'une transformation - notamment culturelle - de la société française" (Capdevieille and Rey, eds. 18).

2 Latter-day visions of May are further distorted by mythical fantasy as defined by Kirk, who studied myths and their meanings in various cultures: May is seen as a fabulous time outside normal experience, when "... all the rules of normal action, normal reasoning and normal relationships may be suspended or distorted" (269; Kirk's italics); consequently, as if by magic, anything suddenly became possible during May. The potential for mythical fantasizing about May has long been evinced by iconic slogans like "soyez réalistes, demandez l'impossible", "prenez vos désirs pour la réalité", "sous les pavés, la plage”, or "en mai fais ce qu'il te plait". Later recollections of a watershed when, in the absence of normal rules, anything became possible, have further encouraged this species of mythologizing. Here are just three examples: Costa-Prades, in a personal memoir, calls May “...cette fabuleuse période de remise en question dans tous les domaines" (7-8); Le Goff, who appraised May's aftermath, remarks that "La rupture avec le vieux monde est censée concerner tous les aspects de la vie, inextricablement mêlés” (82); Hees, when probing May's ongoing relevance, argues that “... Mai réinstituait, pour quelques jours, le 
sens de l'égalité. Dans tous les domaines. Plus de pouvoir officiel, plus de président, plus de Premier ministre, des experts dépassés" (111).

The impact of May on French comics has been discussed. La révolution Pilote 1968-1972 by Aeschimann and Nicoby delves into developments at Pilote magazine. This work takes the form of comic strip interviews with the artists Gotlib, Fred, Druillet, Bretécher, Mandryka and Giraud, who rebelled at Pilote in 1968. Aeschimann and Nicoby demonstrate how Pilote brought French comics to adulthood post 1968, by freeing artists from the constraints of drawing for children; during the late 1960s/early 1970s Pilote introduced its readers to irony, the fantastic, absurdity and graphic experimentation. Rolland, extending the analysis up to the late 1970s, elaborates that May encouraged social criticism, feminism, drugs, explicit sex and more. Despite such interest in May's legacy, surprisingly little has been written about the way French comics represent the events themselves.

May's approaching fiftieth anniversary makes the time exceptionally ripe to re-examine the relationship between the uprising and French comics. This article builds on previous work, by analyzing how comic strip perceptions of May contribute to and/or contest the mythology surrounding the uprising. I draw on critical writings about May and about French comics, as well as on a range of strips. Some of the earlier comics I mention have already been discussed by Aeschiman, Nicoby and Rolland, as well as by other critics notably Groensteen. However I concentrate on comics published from the turn of the millennium, which is to say after May had become fixed in French national mythology; these strips have hitherto received little or no critical attention. I start with pieces contemporaneous to May, and I trace the entry of the uprising into French comics. Next I consider later works which construct myths about May, and creatively exploit the potential for mythical fantasy as defined by Kirk. Finally, I discuss artists who contest the mythology surrounding May through parody, re-appropriation and deconstruction.

\section{May Enters Bandes dessinées}

5 May 1968 did not come out of nowhere. The youthful rebellion had been simmering at least since the early1960s. A magazine called Hara-Kiri, launched in 1960, provided a platform for the new generation of comic strip artists notably Gébé, Reiser and Cabu; it shocked the establishment with subversive satire, nudity and obscene humour (Groensteen 2009, 55-56; Rolland 171). Hara-Kiri was an indication of how French comics would develop. So too was Forest's science fantasy Barbarella, which was published in 1962, and was based around a promiscuous, scantily clad heroine (Groensteen 2009, 116-117; Rolland 173). The magazine Actuel, bears further witness to increasing rebelliousness among French youth; founded in 1967, it carried strips by American Underground artists Crumb and Shelton (Rolland 170).

6 Once the revolt had exploded onto the street during May 1968, strips satirizing current affairs began reacting to events. Le canard enchainé was quick to respond. A piece by Escaro dated 8 May commented on the youthful nature of the rebellion: the captions "Sac", "Bac", "Fac", "Lac (rymogène)" and "Vac", appear beneath a primary schoolboy, an adolescent, a university student, police using teargas, and a youth writing "mort aux vacs" on a wall; his graffiti is an abbreviation of "vaches", a slang word for the police. Soon afterwards, Escaro's "Comment voyez-vous un pavé?" identified the symbolic significance cobblestones were attaining: one cobble lands on De Gaulle's head, while 
another gets lodged in Prime Minister Pompidou's heart. Escaro's "Ça va de soi" alluded to de Gaulle's election announcement and foreshadowed May's dénouement: "Quoi?", "Loi", "Moi", and "Roi (en exile)" are captions beneath a question mark, pictures of police brutality, de Gaulle on television, and de Gaulle exiting like a deposed king. The magazine L'enragé, set up during May 1968 by political activists, attacked de Gaulle's supporters as fascists. In Wolinski's untitled strip, characters agreeing that extremists should be sent to concentration camps echo chants of "Cohen-Bendit à Dachau"; Sirinelli's historical/ political analysis of May records that those chants, which reference the Jewish student leader Daniel Cohn-Bendit, had been heard on a pro-Gaullist demonstration (296).

7 Revolution was in the air at Pilote magazine during May 1968. Artists interviewed recall a stormy meeting with the chief editor Goscinny, which became legendary. Giraud, for one, recognized that Pilote's readers were growing up: they were no longer children, but protestors on the barricades; consequently, defying Goscinny's strict editorial policy, he and several others demanded more say over content, so as to update the magazine's infantile image (Aeschimann and Nicoby 86-88). Soon afterwards Pilote began embracing more adult concerns, and this led to an outpouring of creativity. As Groensteen puts it: "Au cours des années 1968-1972, Pilote atteint une qualité exceptionnelle" (2009, 104). Remarkable strips from this period include, amongst much else, Bretécher's barbed social commentary Salades de saison, and Gotlib's iconoclastic parody Rubrique à brac, which was aimed at students rather than at young children (Groensteen 2009, 104, 111).

8 A less well known strip from an album by Sempé, published later in 1968, gives clues as to how May was going to be mythologized: sequenced images start and end with two almost identical drawings of people voting; in between the unrest is depicted, while a radio announces immanent civil war (Sempé n.pag); the radio references an alarmist statement Pompidou made at the height of the unrest (Sirinelli 271). Sempé, by beginning and ending with pictures of similar elections, suggests that May changed little politically.

9 The tendency to depoliticise May and its legacy, to which Sempé alludes, was first identified by Ross, who demonstrated how the mainstream media transform May's complexities to an easily comprehensible narrative. Over the years depoliticization became a staple of May's mythology. For example the Dictionnaire de Mai 68, when discussing how the "Mai mythique" came into being, mentions "une dépolitisation de Mai 68 dans l'imaginaire collectif" (Capdevieille and Rey, eds. 18). Sempé's strip also shows how May could be turned into the mythical fantasy defined by Kirk in our Introduction: the inference is that all of the rules governing normal democratic procedures were suspended during May, and consequently civil war suddenly became possible.

During the 1970s artists ceased to mention May directly. Nonetheless the legacy of the uprising for comics was apparent, not only at Pilote but also beyond. This period has been extensively documented by critics. In 1970 Charlie hebdo, founded by Cabu, Gébé, Wolinski and others, published biting socio-political satire (Groensteen 2009, 114-5; Rolland 178). Gébé's L'an 01 is particularly in keeping with the May notion that anything was possible: the rules governing the polluting, consumer-oriented, military industrial complex are swept away by an anarchist utopia which enjoys, amongst other things, a "défouloir" enabling people to laugh out loud in the street, and an institute for erotic research. In 1972 Mandryka, Gotlib and Bretécher left Pilote to found L'écho des savanes, which carried abrasive, adult oriented humour (Aeschimann and Nicoby 26, 72; Groensteen 2009, 120; Rolland 178); in 1974 Druillet and Giraud (aka. Moebius) founded Métal hurlant, to provide a forum for experimenting with science fiction (Aeschimann and Nicoby 79; Groensteen 
2009, 120-122; Rolland 184); in 1976 feminism made its presence strongly felt with Ah! Nana, run by the all women team of Claveloux, Cestac and Montellier (Groensteen 2009, 108; Rolland 184).

11 A few artists engaged with May on its tenth anniversary. Bretécher evinced disillusionment by hinting that May had changed nothing, be it politically, socially or culturally: a former activist tries to convince his daughter that she can see him in a TV commemoration; she does not believe he was ever there. Wolinski's "La vérité sur Mai 68" intimated that the mythologizing process had begun, by alluding to fanciful accounts distorting reality: an ex-soixante-huitard maintains that May was started by extraterrestrials.

By the 1980s the post-May 68 artists had successfully turned French comics into an adult form. Even so, the next generation showed little interest in May. Célestin Speculoos. Mai 68 by Bodard and Yann was the first full length bande dessinée album to re-engage with the subject. The album came out in 1993, and the date is not insignificant: it is just five years after 1988 when, as the historian Rioux, the sociologist Zancarini-Fournel, and the Dictionnaire de Mai 68 all concur, May became permanently fixed within French popular mythology (Rioux 58; Zancarini-Fournel 262; Capdevieille and Rey, eds. 18). In Célestin Speculoos. Mai 68 the emphasis is on student unrest in the Quartier Latin, but battles with the police are made amusing by caricatural exaggeration, onomatopoeia and slapstick (See Figure 1). Maite the seditious heroine gets separated from her boyfriend Célestin, and she joins in the fun. She has an affair with Cohn-Bendit, but she is not interested in revolutionary ideology. After her fling Maite is re-united with Célestin, who turns out to be a reactionary policeman. Any political differences between Maite and Célestin melt away as France returns to normal.

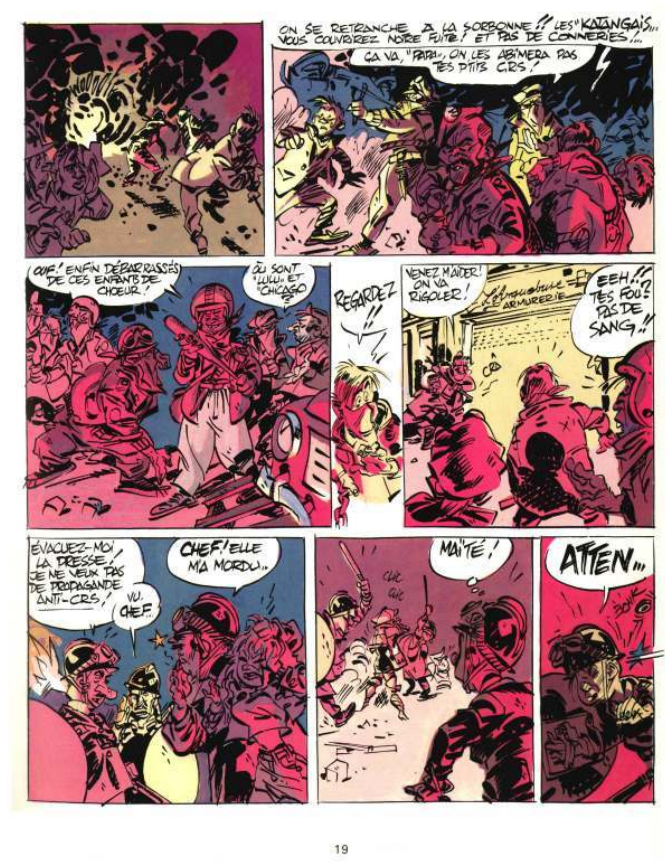

Figure 1: Célestin Speculoos Tome 2 par Yann et D. Bodard @ Editions Glénat 2002 
13 Célestin Speculoos. Mai 68 points towards the mythological May identified by critics. Ross comments that media retrospectives linger over Quartier Latin students, placing emphasis on charismatic legends like Cohn-Bendit; as in Célestin Speculoos. Mai 68 militant ideologies, striking factory workers, and complicated political negotiations are consequently toned down or excluded. Moreover, Rioux attests that by 1988 any lingering memories of May's violent political discord had been eclipsed by a "Mai mythique ... à forte coloration de mise en scène inaugurale de notre libération des moeurs" (58). The Dictionnaire de Mai 68 agrees as to how May was generally perceived at this time: "Mai 68 devient principalement synonyme de révolte étudiante et de libération des moeurs" (Capdevieille and Rey eds., 18). One could add that the liberating May myth has been perpetuated by the absurdist satires, sexual frankness, unbridled fantasies, and daring experiments, of artists from the soixante-generation whom we mentioned above. As Rolland comments when assessing how May's influence over comics looked years later: "On en retient pourtant bien souvent, illusion d'optique, une culture visuelle festive, colorée, et joussive à laquelle contribuent le dynamitage des planches et du récit” (184).

Just over ten years later La malédiction de Zener. Sibylle, the first album in a trilogy by Grangé and Adamov, returned to May. The heroine Sibylle is a clairvoyant, who participates in trials with a communist parapsychology professor during 1968. As May gathers pace, her hallucinations of monsters and space craft increasingly invade the mimetically realistic 1960 s decor. The professor persuades Sibylle to go to Eastern Europe, and the story moves on from May. La malédiction de Zener. Sibylle, despite having political potential, downplays communist ideology in favour of reworking an ancient myth: the Soviets are building Herculean "surhomme" with powers beyond the lot of mortals.

Célestin Speculoos. Mai 68 and La malédiction de Zener. Sibylle could scarcely be more different. The one is knockabout comedy, the other is a disturbing supernatural tale. Nonetheless, Célestin Speculoos. Mai 68 and La malédiction de Zener. Sibylle do share a common feature. They both mark May's entrance into French comics under the guise of what Kirk called mythical fantasy: neither album depicts May in line with demonstrable fact; May is remembered instead as a fantastic time when the ordinary rules governing behaviour were suspended, everyday reasoning became untenable, and what was formerly impossible occurred.

\section{Building May's Mythology}

May's fortieth anniversary in 2008 aroused widespread interest. Cespedes' investigation into May's philosophical import suggests that anti-globalization had reinvigorated the inheritance of the uprising (98); Cusset and Zancarini-Fournel recall that riots and strikes in 2005, followed by student discontent in 2006-2007, were provoking comparisons with May (Cusset 99; Zancarini-Fournel 9); the Dictionnaire de Mai 68 notes how the conservative Presidential candidate Sarkozy's talk of liquidating May's legacy ensured the events remained newsworthy, a point Zancarini-Fournel reiterates (Capdevieille and Rey, eds. 20; Zancarini-Fournel 9). Other critics acknowledge that myth-making had triumphed over reality. Sirinelli regretted that May was a shared deformation of the real: "Les générations suivantes reçoivent encore des récits... le plus souvent mythiques de cet événement 68. Le mot 'mythe' est entendu ici dans son sens le plus commun et le plus neutre: 'une déformation de la réalité devenue collective'" (12). Rotman, when explaining 
May to younger readers, made an almost identical observation: "Mai a produit une vaste mythologie - nourrie de légendes, d'idées préconçues, de partis pris idéologiques, très éloignée de la réalité historique" (13). The revival of interest recurred in French comics; it is no accident that most of the strips we study below were published from the late 2000s onwards. In the coming section we consider two albums which build up the mythology around May.

May 68. Histoire d'un printemps by Franc and Bureau is a historical reconstruction, with much space devoted to striking workers and to political negotiations. Cohn-Bendit wrote a laudatory preface. Franc and Bureau are well aware that May is being mythologized: May 68. Histoire d'un printemps is based around Paul, a postgraduate researcher into "le mythe soixante-huitarde dans le discours politique en France 1968-2008" (7). As developments unfold a cast of students, activists, workers and politicians recount their experiences, but without analyzing the said myth. May is drawn with uncomplicated graphics: people and decor are sparingly sketched in; violence is toned down; the only colours are black, white, red and dark blue. As May reaches its zenith, fantasy pervades the proceedings: a sub-plot idealizes Cohn-Bendit as Don Juan, when somebody impresses female students by pretending to be him (67); Philippus the prophet from Hergé's L'étoile mystérieuse appears on a demonstration (66); when the Odeon theatre is occupied, someone mimics Haddock's antics from Hergé's Les sept boules de cristal by putting a cow's head on (77).

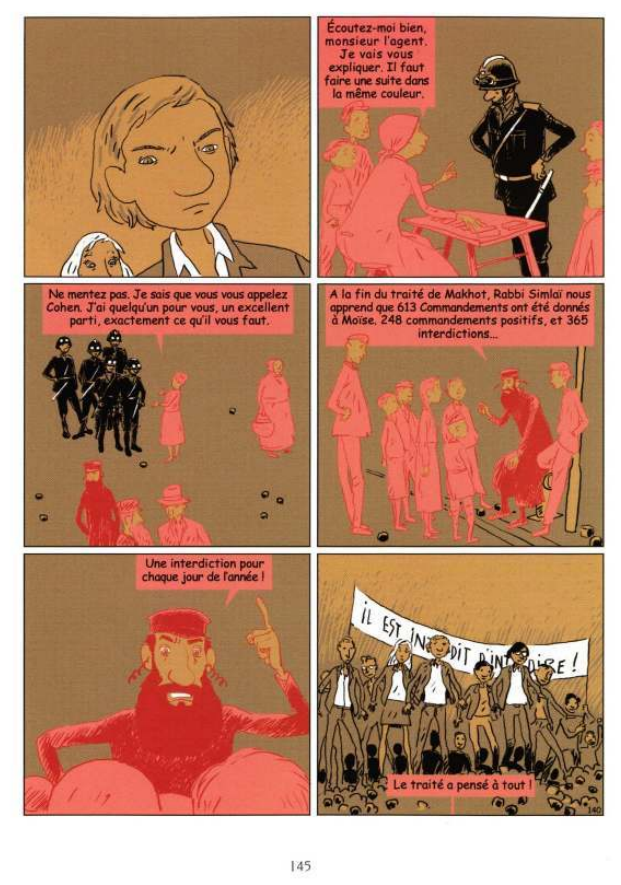

Figure 2: Le Pavé Originel, Pianko et Winz (c) Editions DELCOURT, 2009

The conclusion reviews May's legacy largely positively: May ended post-colonial Gaullist paternalism, while enabling "le rejet de codes sociaux et moraux dépassés" (106). However May's underlying complexities are barely considered. For example May's relationship with collectivism and individualism is contentious: Le Goff remarks that some commentators see May as individualist, as does Cusset (Le Goff 20; Cusset 87); 
Cespedes and Hees highlight May's collectivism as much as its individualism (Cespedes 174; Hees 126); Rotman sees no link between individualism and May (147-149). Yet Paul glosses over such difficulties, by simply asserting that individualism trumped politics: "Quarante ans plus après, le bilan est clair: C'est l'individualisme qui l'a emporté sur le combat politique" (107). Paul offers little supporting evidence, beyond restating the conventional view espoused by the media that May's impact was chiefly socio-cultural rather than political: "Plus que la sphère politique, c'est bien la sphère sociale et culturelle qui s'est trouvée bouleversée" (107).

May 68. Histoire d'un printemps purports to reveal the truth behind the May myth, and the album does include the striking workers and political negotiations which are usually excluded from latter-day accounts. Even so, Paul ends up uncritically endorsing the "Mai mythique". His study with its neat graphics, sanitized violence and innocuous fantasies, is an allegory of socio-cultural liberation: May is thereby explained away as a benign, modernizing transformation, as distinct from a potentially revolutionary explosion of bloody discontent; the cheekily telegenic Cohn-Bendit, whom May 68. Histoire d'un printemps elevates to heroic status, exemplifies this good-natured and modernizing myth, as Delporte observed when analyzing May's iconography (344-347).

If May 68. Histoire d'un printemps re-tells a well rehearsed myth, then Le pavé originel by Pianko and Winz is less orthodox: it creates a new hero who embodies May's myth of origin. The whimsical artwork and preoccupation with Jewish identity owe much to Sfar. The hero Sam Opianski, a son of devout Jewish refugees, epitomizes the 1960s generation caught between radicalism and conservatism. Sam admires communism, yet he accepts a managerial position in his father's clothing business, where he seduces female models. Sam faces family pressure to marry and a bride is chosen for him, but he elopes with a rebellious young woman. They get caught up in disturbances outside the Sorbonne on 3 May, which is the date of the first serious Quartier Latin unrest. Sam's ultra-traditionalist ancestors, whose advice to him punctuates the story, materialize on the barricades (144-149 - see Figure 2). Sam, in exasperation, throws May's first cobblestone. It hits the head of a policeman who blends into his father, and the rioting starts.

21 Sam casting the first stone deforms reality: the first cobble hit an officer in a van (Sirinelli 77-8). However, Sam simultaneously gives May's origin a mythical explanation by answering a question Rotman raises: why was 3 May the major turning point (59)? Sam is rooted in mid/late 1960s France, and his action exemplifies the rejection of patriarchal authority frequently associated with May (Aeschimann and Nicoby 62, 139; Capdevieille and Rey , eds. 12; Costa-Prades 83; Le Goff 18, 34). Nonetheless Sam, resonating beyond his place and time, re-works a myth Kirk defines as "the displacement of elders" $(195,199$, 205). This myth accounts for family tensions caused by succeeding generations, and its most famous exemplar is of course Oedipus. Not only that: Sam also enjoys the global reach of Campbell's "composite hero of monomyth" (245). Sam, like innumerable mythical heroes, ventures beyond his community's sphere of activity; this happens thanks to his political and sexual proclivities. Sam has exceptional powers insofar as he can communicate with his dead ancestors. Sam encounters helpers and hinderers, but he ultimately triumphs: Sam vanquishes the tyrant (his father/the policeman), and he gives society a redemptive boon - symbolised here by the cobblestone. Le pavé originel makes a significant contribution to building May's mythology: it distorts May into a fabulous tale, whose hero personifies commonly accepted popular beliefs about succeeding generations. 


\section{May's Mythical Fantasy}

In 2008 two compilations appeared: Pilote. 60 auteurs de BD réinventent Mai 68 and Le pavé de la bande dessinée. Mai 68; we shall return to them under the titles Pilote and Pavé. Among the strips here are short gags by young artists who exploit May's potential for the mythical fantasy Kirk identified: May is remembered as a time when, as if by magic, the normally accepted rules governing actions, reasoning and relationships unexpectedly ceased to apply; consequently, what was formerly impossible could be achieved. In one example among many Zanzim's rebellious teenager defies her father, and climbs out of the bedroom window to join a demonstration; she loses her skirt en route, so she steals trousers from an old man's washing line; suddenly she is leading the protest. The astonishing metamorphosis also affects colonized ethnic minorities: in a send-up of Jacobs' Blake and Mortimer by Barral and Veys, the faithful Indian servant goes on strike during May. In such gags, mythical fantasy explains the complex socio-cultural transformations which May arguably brought about: history is simplified into an exemplary mini-allegory, where an individual's liberation symbolizes the feminism and the anti-colonialism widely associated with the uprising.

In two lengthy graphic novels, L'écharde by Duvivier and Giroud and L'enfant maudit by Galandon and Monin, mythical fantasy acquires a more literary dimension: relatively complex plots allow greater psychological development; interest resides in exploring the impact May had over what went through the main character's mind. L'écharde has panoramic views, intimate interiors, and period local colour reminiscent of Bourgeon's 18 th century saga Les passagers $d u$ vent, albeit with the setting updated. L'enfant maudit has angular caricatures not unlike those of Blain.

In L'écharde, Annette takes an injured boyfriend to hospital after a demonstration; a nurse there comments on Annette's resemblance to a woman whose birth she attended during World War 2 (42). In L'enfant maudit Gabriel is arrested; one policeman apparently recognises him, calling him a "rejeton de boche" (18). Annette's and Gabriel's curiosity is aroused, so s/he embarks on a quest to discover their true identity. Gabriel's mother turns out to have been a collaborator. Annette discovers that her family are Jews, and that her mother Marie-Louise had a sister called Julienne, who gave birth to a baby girl before being deported by the Gestapo. Annette subsequently ascertains that Julienne was her real mother. Marie-Louise, who is actually her aunt, betrayed Julienne out of jealousy.

L'écharde and L'enfant maudit provide unusual variants to May's mythical fantasy: they both show the personal repercussions on the subject of a moment when the rules governing the characters' family relationships suddenly disappeared, and the formerly inconceivable occurred; May triggers a chance encounter with life-altering consequences for the two the main protagonists.

Mythical fantasizing has also given rise to two counterfactual dystopias: L'imagination au pouvoir? and Paris brûle encore by Duval, Jean-Blanchard, Mr Fab and Damien. In L'imagination au pouvoir? Paris becomes devoted to hedonism under a victorious CohnBendit; the alarmed US President Nixon secretly converts Mitterrand to the Washington consensus, in a nod to French Atlanticism when the Socialists won the 1981 election. In Paris brûle encore de Gaulle's assassination provokes nuclear civil war, and Paris degenerates into a gang-infested nightmare until the UN intervenes (see Figure 3). As 
with L'imagination au pouvoir? France reverts to history under a centre-left government: the presidential candidate for the $6^{\text {th }}$ Republic is Mitterrand's minister Rocard.

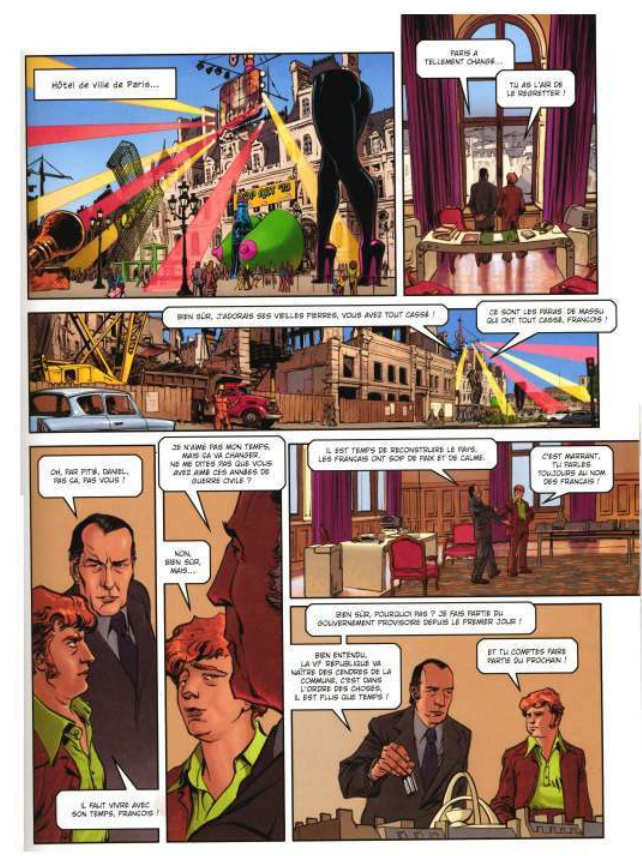

Figure 3: Jour J, volume 6, Duval - Pécau - Blanchard__ Mr Fab @ Editions DELCOURT, 2011

Since May first entered French comics as a mythical fantasy with Sempé, we have seen the multiple possibilities offered by this popular tradition: one light-hearted comedy, one supernatural thriller, two humorous gags, two historical novels, and two counterfactual speculations, all re-create May as an exceptional time when rules ceased to apply and anything became possible. No doubt future artists will productively exploit this fruitful branch of May's mythology.

\section{Contesting the Reigning Mythology}

The artists considered thus far contribute to building myths around May. Other artists, however, are more sceptical about May's mythological accompaniment. This section examines comics which contest the reigning mythology. We begin with five parodies from Pilote and Pavé. As Groensteen points out when quoting Sangsue, parody "implique fondamentalement une relation critique à l'objet parodié" (2010, 7; Groensteen's italics). Thus, Relom's critical parody of TV retrospectives exaggerates the socio-cultural liberation which the media attributes to the "Mai mythique": May gave us video games, topless women, and men who push prams. Rossi and Sapin take mythical fantasizing about May beyond reasonable comment: the hero, a shy, bullied misfit, makes love with a beautiful woman, and he becomes a respected radical; she gives birth to an anthropomorphic chipmunk who gets killed by a cobblestone; after May the hero reverts to being his former self.

Artists who link May to contemporaneous current affairs parodically over-state the legacy of the uprising. Riss, endowing May with sinister numerological magic, 
hypothesizes that 68 is cursed; he intimates too that Sarkozy's right-wing agenda demonizing May is based on fearful ignorance. Riss runs through rebellions down the ages, including the Dutch iconoclasts' revolt of 1568 and the Cuban insurrection of 1868 . In 2008 a middle aged man idly tosses an under-sized cobble towards a cowering policeman, making Sarkozy flee in terror.

Artists further question May's legacy by deriding ex-soixante-huitards, who ended up becoming everything they formerly opposed. Monsieur B's one-time revolutionary firebrand enriches himself by recycling cobblestones. Ghorbani's talking Citroën DS, a luxury car, tells how it was vandalized by a young radical, only to be lovingly restored by him in later life. Monsieur B and Ghorbani suggest that, despite the popular myth of May ushering in socio-cultural transformation, very little actually changed; the two strips also remind readers of May's revolutionary political militancy which, they suggest, was subsequently betrayed and/or forgotten.

31 The 2008 boxed set 1968-2008. N'effacez pas nos traces! contests the reigning mythology around May from a different angle. It is a CD of fifteen songs by Grange plus an illustrated booklet by Tardi. Grange, like many others, idealizes May as a mythical fantasy when anything seemed achievable: "Le temps n'avait pas d'importance puisque tout nous semblait possible... y compris l'impossible" (8). Grange's lyrics and Tardi's artwork enhance the fantastic potential with symbolic imagery: freedom is a child-like creature, policemen are reptiles or vultures, and a man falls from the sky into a bed of cherries ("La Commune est en lutte" 29,"Chacun de vous êtes concerné" 17, "Entre océan et cordillière" 34, "Le temps des cerises" 50-51). Quite exceptionally however, mythical fantasy challenges the prevailing deformations of reality. In 1968-2008. N'effacez pas nos traces! May, linked to other uprisings through music and symbolic imagery, continues a timeless story: humanity's fight for justice. As a consequence May's myth is redefined as a tale of universal significance, passed down the generations, and kept alive within popular folklore.

1968-2008. N'effacez pas nos traces! redefines May by dwelling on what the dominant mythology edits out: radical politics, striking factories, and police violence. Only two pieces deal primarily with the Quartier Latin ("Chacun de vous êtes concerné" 17-21 and "La pègre" 54-56). In "La pègre", graffiti reading "FLN vaincra" associates May with the Algerian war; Algeria fuelled May's anti-colonialism, although it is excised from official versions of events (Ross 34-62 - see Figure 4). Other pieces accord workers and students equal space ("Grêve illimitée" 13-16), or else they concentrate on the workers ("Pierrot est tombé" 22-25, "Les nouveaux partisans" 56-61, "N’effacez pas nos traces" 60-64). The terms of reference include the French Revolution, as when the FLN graffiti appears on the pedestal of Georges Danton (1759-1794); the $19^{\text {th }}$ Century Commune, Pinochet's dictatorship, and today's asylum seekers are also specifically mentioned ("Le temps des cerises", "Entre océan et cordillière", "Droit d'asyle" 52-53). Oppressors are faced down by little people, not by mythical heroes like Cohn-Bendit: these include Pierrot the eponymous worker, and a prisoner of conscience ("Toujours rebelles, toujours debout" 48-49). 

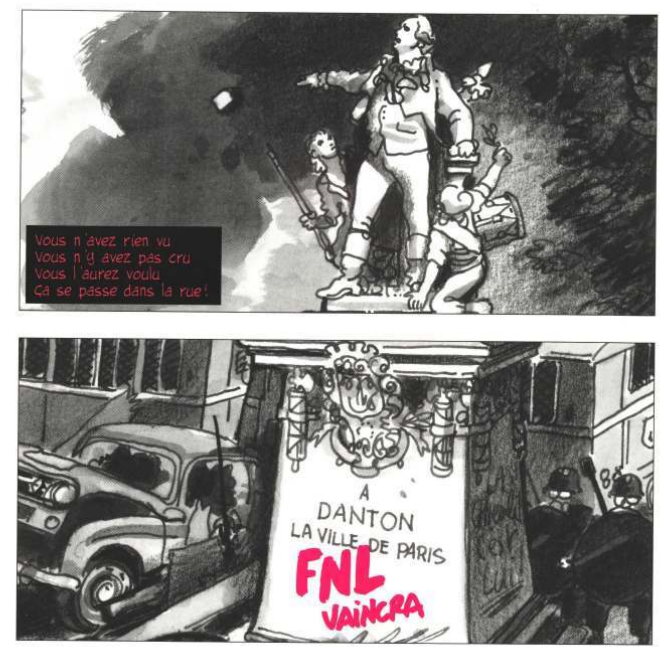

Figure 4: @ Editions Casterman S.A./Tardi et Grange : <a href ="HYPERLINK http:// www.casterman.com">Editions Casterman $</ a>$ mythical fantasy that May made anything possible, by describing an attempt to bring it into reality. La communauté is based on interviews with genuinely existing people, who set up a self-sufficient commune in May's aftermath. One member recalls: "Tout était possible... On allait pouvoir agir et mettre en pratique tout ce qu'on avait pensé faire en 68" (35-36). Mythical fantasy made the ideal of communal living outside the nuclear family possible; but it collapses when tested against psychological, social and economic truths. As May's tensions between individualism and collectivism are played out within the group at a practical level, everything is not possible. Money worries, ethical dilemmas, interpersonal frictions and everyday chores are documented. Artistically inclined members design posters for supermarkets and for advertising companies, alleging that "on n'avait pas le choix" (117); they want expensive cars, because their shared Citroën Dyane "ne fait pas sérieux... dans le monde très classique du commerce" (273). Some members are tempted by consumer goods, much to the disapproval of other factions (286-288). After an accidental fire, exacerbated by lack of fire-proofing, the project is abandoned. live on different planets, fly through the air, and change size $(67,85,267)$; talking mice comment, and, in a jocular reference to Hergé's L'affaire Tournesol, the local butcher is named Sanzot $(136,225)$. Whilst dismantling a myth need not preclude innocent fancies, they are unusual in critical, research-based sociological studies such as this. Nevertheless, lack of graphic realism does fit the pattern for other comics we have considered in this section: it recurs not only in the critical parodies of Pilote and Pavé, but also in the luxuriant fantasmagoria of May 1968-2008. N'effacez pas vos traces!. These comic strips all 
demonstrate that May, by the $21^{\text {st }}$ Century, had become closely associated with fantasy, including amongst sceptics who contested the reigning mythology.

\section{Conclusion} simmering revolt first burst out Escaro and Wolinski immediately reacted to unfolding
developments. Soon afterwards Sempé noticed the possibility for May's mythical fantasy, whilst touching on the idea that nothing happened politically; both elements were to become essential to the dominant mythology. During the 1970s, the rebellious post soixante-huitard artists broke with convention, and their innovations brought French comics into adulthood. On May's tenth anniversary Bretécher expressed disillusionment and Wolinski hinted at the nascent mythologizing. Comic strip artists turned away May during the 1980s. Even so by 1988, as Rioux, Zancarini-Fournel, and the Dictionnaire de Mai 68 agree, May had become a fixture within the national mythology. Subsequently, during the decades on either side of the millennium May, re-entered French comics as a mythical fantasy with Célestin Speculoos. Mai 68 and La malédiction de Zener. Sibylle. By 2008, as Rotman, Sirinelli and others observe, May was morphing into a collective deformation of reality. Mai 68. Histoire d'un printemps shows how swathes of the community remembered May at the time: it disseminates the myth of a benign, socio-cultural watershed, which is propagated by the media and embodied by Cohn-Bendit. Le pavé originel, making a bolder move, proposes an explanatory myth of origin. Other artists rework the mythical fantasy with which May is habitually associated in the public imagination. This time-honored trope generates humour in Pilote and Pavé, furthers characterization in L'écharde and L'enfant maudit, and permits counterfactual conjectures in L'imagination au pouvoir? and Paris brûle encore.

A section of the public is more critical of the dominant mythology surrounding May, as we have seen. Thus, parodists lampoon the socio-cultural significance customarily attributed to May and to its legacy. Tardi and Grange are engaged in a more serious struggle for May's memory: 1968-2008. N'effacez pas nos traces! redefines May as a symbol of humanity's eternal struggle against injustice. Finally, La communauté dismantles the myth that everything was possible with disarmingly innocent graphics.

Since May last caught the public eye in 2008 new preoccupations have come to the fore, particularly the prolonged economic crisis, and the rise of Islamic terrorism. Even so we assume that later artists will engage with May, as the rebellion continues to arouse interest. May's approaching fiftieth anniversary begs questions about how artists will respond. The terrorist murders of May veterans Wolinski and Cabu at Charlie hebdo in January 2015 will presumably provoke comment. The dramatic and humorous variations mythical fantasy offers are inexhaustible. There is room for more new mythological heroes alongside Sam Opianski and the characters from 1968-2008. N'effacez pas nos traces!. The reclamation of May's myth Grange and Tardi initiated has barely started. Depictions of factory workers in Mai 68. Histoire d'un printemps, L'enfant maudit and 1968-2008. N'effacez pas nos traces! are further avenues to explore; so too is police misconduct in L'écharde, L'enfant maudit and 1968-2008. N'effacez pas nos traces!. Linking May into global events, a tendency running through Le pavé originel, L'écharde, L'enfant maudit, L'imagination au pouvoir? and Paris brûle encore, up to 1968-2008. N'effacez pas nos traces! has already proven productive. Tanquerelle's and Benoit's deconstruction constitutes yet another potentially 
fruitful possibility; there is still no rigorous analysis of May in French comics. At the time of writing commemorative publications have yet to be announced. We await developments with interest.

\section{BIBLIOGRAPHY}

Aeschimann, Éric and Nicoby [Nicolas Bidet]. La révolution Pilote 1968-1972. Paris: Dargaud, 2015. Barral, Nicolas and Pierre Veys. "Philippe et Francis." Pilote. 60 auteurs réinventent Mai 68. Paris: Dargaud, 2008: 150-151.

Bodard, Denis and Yann [Yann le Pennetier]. Célestin Speculoos. Mai 68. Grenoble: Glénat, 1993. Bretécher, Claire. "Les frustrés." Nouvel Observateur [Paris]. 15 May 1978: 99.

Campbell, Joseph. The Hero with a Thousand Faces. 1949. London: Fontana, 1993.

Capdevieille, Jacques and Henri Rey, eds. Dictionnaire de Mai 68. Paris: Larousse, 2008.

Cespedes, Vincent. Mai 68. La philosophie est dans la rue. Paris: Larousse, 2008.

Costa-Prades, Bernadette. Tu te souviens de 68? Une histoire intime et affectueuse. Paris: Albin Michel, 2008.

Cusset, François. Contre discours de Mai. Ce qu'embaumeurs et fossoyeurs de 68 ne disent pas à ses héritiers. Arles: Actes Sud, 2008.

Delporte, Christian. “Mai 68. De l'image à l'icône.” Images et sons de Mai 68. 1968-2008. Ed. Christian Delporte, Denis Maréchal, Caroline Moine and Isabelle Veyrat-Masson. Paris: Nouveau monde, 2011: 335-353

Duval, Fred, Jean-Pierre Blanchard and Mr Fab [Fabien Esnard-Lascombe]. L'Imagination au pouvoir? Paris: Delcourt, 2011.

Duval, Fred, Jean-Pierre Blanchard and Damien [Damien Cuvillier]. Paris brûle encore. Paris: Delcourt, 2012.

Duvivier, Marianne and Franck Giroud. Intégrale. L'écharde. 2004-2006. Paris: Dupuis, 2010.

Escaro, André. Untitled comic strip. Canard enchaîné [Paris]. 8 May 1968: 12.

“Comment voyez-vous un pavé?” Canard enchaîné [Paris]. 15 May 1968: 5.

“Ça va de soi." Canard enchaîné [Paris]. 30 May 1968: 8.

Franc, Alexandre and Arnaud Bureau. Mai 68. Histoire d'un printemps. Paris: Berg International, 2008.

Galandon, Laurent and Arno Monin. L'enfant maudit. Les tondues. Charnay lès Macon: Bamboo, 2009.

Gébé [Georges Blondeaux], L’An 01. 1971-1974. Paris: L'Association, 2014.

Ghorbani, Cédric. Untitled comic strip. Mai 68. Le pavé de la bande dessinée. Ed. Clotilde Vu and Jean Wacquet. Paris: Soleil, 2008: 14-16. 
Grange, Dominique and Jacques Tardi. 1968-2008. N'effacez pas nos traces! Paris: Casterman, 2008. Grangé, Jean-Christophe and Philippe Adamov. La malédiction de Zener. Sibylle. Paris: Albin Michel, 2004.

Groensteen, Thierry. La bande dessinée. Son histoire et ses maîtres. Paris: Skira Flammarion, 2009.

Parodies. La bande dessinée au second degré. Paris: Skira Flammarion, 2010.

Hees, Jean-Luc. Le roman de Mai 68. Paris: Rocher, 2008.

Hergé [Georges Remi]. L'étoile mystérieuse. Tournai: Casterman, 1942.

Les sept boules de cristal. Tournai: Casterman, 1948.

L'affaire Tournesol.Tournai: Casterman, 1956.

Kirk, Geoffrey. Myth. Its Meaning and Functions in Ancient and Other Cultures. Cambridge: CUP, 1970.

Le Goff. Jean-Pierre. Mai 68. L'héritage impossible. Paris: La Découverte, 1998.

Monsieur B [Bertrand Marceau]. Untitled comic strip. Mai 68. Le pavé de la bande dessinée. Ed.

Clotilde Vu and Jean Wacquet. Paris: Soleil, 2008: 82-84.

Pianko, Adam and Nicolas Winz. Le pavé originel. Paris: Delcourt, 2009.

Relom [Olivier Morel]. “Mai 68 expliqué aux moins de 50 ans." Pilote. 60 auteurs réinventent Mai 68. Paris: Dargaud, 2008: 70-71.

Rioux, Jean-Pierre. “À propos des célébrations décennales du Mai français.” L'Histoire. 1989. 23.1: 49-58. Web. 05/12/16.

Riss [Laurent Sourisseau]. “68 année maudite.” Pilote. 60 auteurs réinventent Mai 68. Paris: Dargaud, 2008: 76-77.

Rolland, Michaël. "L'Underground et la culture visuelle des années 68 en France: l'exemple des bandes dessinées." Images et sons de Mai 68. 1968-2008. Ed. Christian

Delporte, Denis Maréchal, Caroline Moine and Isabelle Veyrat-Masson. Paris: Nouveau monde, 2011: 169-184.

Ross, Kristin. May'68 and its Afterlives. Chicago and London: University of Chicago Press, 2002. Rossi, Christian and Mathieu Sapin. “L'esprit de Mai.” Pilote. 60 auteurs réinventent Mai 68. Paris: Dargaud, 2008: 138-141.

Rotman, Patrick. Mai 68 raconté à ceux qui ne l'ont pas vécu. Paris: Seuil, 2008.

Sempé, Jean-Jacques. L'information consommation. Paris: Denoël, 1968.

Sirinelli, Jean-François. Mai 68. L'événement Janus. Paris: Fayard, 2008.

Tanquerelle, Hervé and Yann Benoît. Intégrale. La communauté. 2008-2010. Paris: Futuropolis, 2010.

Wolinski, Georges. Untitled comic strip. Enragé [Paris]. 1 July 1968. n.pag.

“La vérité sur Mai 68." Charlie hebdo [Paris]. 4 May 1978: 48.

Zancarini-Fournel, Michelle. Le moment 68, une histoire contestée. Paris: Seuil, 2008.

Zanzim [Frédéric Leutelier]. “Le Pantalon.” Pilote. 60 auteurs réinventent Mai 68. Paris: Dargaud, 2008: 142-145. 


\section{ABSTRACTS}

The events of May 1968 have entered the French national mythology in the form of a simplified and exemplary narrative: May is generally believed to have been a student-led uprising, whose transformative legacy was socio-cultural rather than political. Popular perceptions of May also contain strong elements of mythical fantasy as defined by the mythologist Geoffrey Kirk: all the rules governing normal actions, normal reasoning and normal relationships were suspended or distorted during May; consequently, as if by magic, anything suddenly became possible. Vast amounts have been written about May and about its mythological accompaniment. Studies have also been carried out into how May influenced French comic strips, notably by Aeschimann and Nicoby, as well as by Rolland. However, hardly anything has yet been said about the way the uprising itself is evoked in comic strips, despite their being a key aspect of French popular culture. This article fills a gap by studying comic strip representations of May. I draw on previous critical writings about May and about French comics, as well as on a range of strips, most of which have hitherto received little or no critical attention. The coming pages consider a historical reconstruction, a sociological study, a light-hearted comedy, a tale of the supernatural, and a CD booklet, as well as two graphic novels, two counter-factual dystopias, and various parodies. My purpose is to examine how these comics contribute to and/or contest the mythology that has grown up around May. We shall see that several artists construct myths about May, as well as exploiting the multiple possibilities mythical fantasy offers; other artists are more critical of May's attendant mythology. However, all of the comic strips indicate that May has come to be remembered via a collective deformation of reality, which no longer corresponds to historical fact.

\section{INDEX}

Mots-clés: bande dessinée, culture populaire, histoire culturelle, Mai 68, mythologie

\section{AUTHOR}

\section{MATTHEW SCREECH}

Manchester Metropolitan University

Matthew Screech is senior lecturer in French at the Manchester Metropolitan University. He has written and published extensively about bandes dessineés including the book Masters of the Ninth Art (Liverpool University Press, 2005). He has also published articles about Edmond Baudoin, adaptations of Voltaire's Candide, Tintin in political cartoons, and Carollian nonsense effects in Philémon. His most recent publication was a chapter titled 'Continuing Clear Line 1983-2013'. This study of how later artists have used Hergé's graphic style was published in The Comics of Hergé: When the Lines are not so Clear (University Press of Mississippi, 2016). Matthew is a founder member of the International Bande Dessinée Society and he sits on the editorial board of European Comic Art. He has been invited to speak about BDs at L'Université Libre de Bruxelles, Dartmouth College New Hampshire USA, and the Hergé museum Louvain la Neuve Belgium. 